\title{
Discussion on the Overall Risk Hedging for "Expansion of Investment" of Social Security Fund
}

\author{
Ying Huang \\ School of Economics \\ Sichuan University \\ Chengdu, China
}

\author{
Ting He \\ Lijiang Central Branch of People's Bank of China \\ Lijiang, China
}

\begin{abstract}
In recent years, Chinese government has made moderate "expansion" on the investment scope of national social security fund, which provides the conditions for the social security fund to play a stronger role in the strategic reserve of social security, but brings new risks in the investment of social security fund in local government debt, direct equity investment, trust and loan investment and other aspects. The author believes that the establishment of a comprehensive hedge mechanism and continuous expansion of investment is the necessary way to control the investment risk of social security fund. Accordingly, the author proposes the risk of hedge securities market of opening social security fund in investment of stock index futures products, physical gold, gold futures and margin trading products, allows the introduction of security mechanisms and purchase of guarantee services when social security funds invest in local debt and provides a series of countermeasures and suggestions like introduction of re-guarantee mechanism for the risk prevention and control of trust product investment.
\end{abstract}

Keywords-social security fund; expansion of investment; risk hedge

\section{INTRODUCTION}

At present, many countries in the world have established a national social security reserve system, which plays the role of strategic reserve and security in the social security expenditure in future. Since China decided to moderately expand the investment of the National Social Security Fund (hereinafter referred to as the "Social Security Fund") at the State Council executive meeting in 2015, it provides the condition and opportunity for social security fund to play a stronger role of strategic reserve in the national social security funds but it brings challenges for how to control the new investment risk after the expansion of investment of the social security fund. On April 1st, 2015, at the executive meeting of the State Council presided by the State Council Premier Li Keqiang, he proposed to properly expand the investment national social security fund of 1.5 trillion, allowing it to invest in local government bond business and raising the proportion limit of investment in corporate bonds and local government debt to $20 \%$. The scope of direct

This article is the phased achievement of national social science fund major bidding project- "research on realization mechanism and the monitoring system of equalization between urban and rural basic public service" (14ZDA030). equity investment is expanded to the central enterprises and their subsidiaries and local leading enterprises, the proportion limit of investment in trust loans from increases from $5 \%$ to $10 \%$, and investment in the negotiable certificate of deposit of national inter-bank market is allowed. ${ }^{1}$ Since then, a series of measures including the Interim Procedures for Trust loan investment Management of National Social Security Fund (revised in 2016) (Social Security Fund Office [2016] 97) that aims at the investment management and risk control of "expansion of investment". Expansion of investment of Social security fund can make the social security fund achieve multi-channel appreciation on investments, but arouse wide discussion of the whole society on the new investment risk and its defense after "expansion of investment".

\section{THE CONNOTATION AND STRATEGIC SIGNIFICANCE OF NATIONAL SOCIAL SECURITY FUND}

With the trend of population aging in the world, the financial crisis and payment crisis in some countries are becoming more and more serious. The problem of preservation and appreciation of the social security fund at the national level as the social security reserve has become a major issue for all governments. The social security fund is divided into three types according to the source of funds and the investment management mode, including the reserve social security fund, the minimum social security fund and the supplementary social security fund or other commercial social security funds (such as various types of private retirement accounts in the United States). ${ }^{2}$ According to the definition of the National Council for Social Security Fund, the national social security funds established in China in 2000 belongs to the reserve fund, which is composed of allocation of the central budget, transfer of state capital, the fund investment income and other ways approved by The State Council, dedicated to the supplement and adjustment

Chen Yan. Investment expansion of 1.5 trillion national social security fund Portal of central government

http://www.gov.cn/xinwen/2015-04/02/content_2841808.htm, 2015-0402/2017-07-02.

Li Xiangjun. Research on Investment Management of Social Security Fund in China Chinese academy of fiscal sciences, 2010 
of social security expenditure like pension insurance in the peak time of aging population. ${ }^{3}$

It should be noticed that because National Social Security Fund plays the role of strategic reserve, which mainly exert the effect of security on the shortage of funds resulting from the surge in social security expenditure including pension insurance in the peak time of population aging, rather than be used for the pay-as-you-go social security, it is different from the basic pension and basic medical insurance system managed by local government since the sources of funding and operation and management are different, and usage is significantly different as well. ${ }^{4}$

National Social Security Fund is an important capital to protect the people's livelihood, so appropriate expansion of fund investment that can stabilize and improve investment income to achieve the preserve or increase the value of the fund is in line with the fundamental interests of the people. At the same time, the social security fund is the "survival money" of the public, which must firmly hold the "red line" of safety ${ }^{5}$, so the first management criteria of social security fund is safety, followed by appreciation. ${ }^{6}$ As social security financing in China transform from the current pay-as-yougo to part of accumulation, the national social security fund balance grows rapidly. Up to the end of 2014, the national social security fund has reached 1528.96 billion yuan ${ }^{7}$. The giant capital reservoir should not only protect the safety of funds, but also face the enormous pressure of appreciation on investments.

\section{THE NECESSITY OF RESEARCH ON THE RISKS AND} HEDGING IN THE INVESTMENT OF SOCIAL SECURITY FUNDS FROM THE PRACTICE IN CHINA AND JAPAN

\section{A. Research on the Existing Risk from the Practice of Social Security Fund in China}

Observing from history of social security fund investment in China and the current product composition of investment, there are risks and hidden worries. According to the report "Social Security Fund Management and Budget Performance in 2013 and Other Financial Revenue and Expenditure Audit Results" issued by Audit Office in 2014, the social insurance fund self-indexed portfolio losses in China from 2010 to 2013 totaled 6.953 billion yuan, in which the loss in 2013 is 1.47 billion yuan. Continuous

\footnotetext{
National Council for social security fund

http://www.ssf.gov.cn/jj/qgsbjj/201501/t20150121_6316.html, 2015-01-21. National Council for social security fund http://www.ssf.gov.cn/jj/qgsbjj/201501/t20150121_6316.html, 2015-01-21.

Chen Yan. Investment expansion of 1.5 trillion national social security fund Portal of central government http://www.gov.cn/xinwen/2015-04/02/content_2841808.htm, 2015-0402/2017-07-02。

Wu Zhong, Wang Yuxi. Risk management model of social security fund investment based on CDaR theory, Business Studies, 2009 (387): 106.

Chen Yan. Investment expansion of 1.5 trillion national social security fund Portal of central government http://www.gov.cn/xinwen/2015-04/02/content_2841808.htm, 2015-0402/2017-07-02.
}

decline of the stock market is the direct cause for the loss while the lack of effective risk hedging way of investment subject of social security fund is a more serious factor. Therefore, under the background of the "expansion of investment", social security fund urgently need to expand the risk hedging way, in order to create system guarantee for achieving preserve or increase the value of social security fund and truly play role of strategic reserve of social security fund.

\section{B. Practical Lessons and Enlightenment of Social Security Fund Investment in Japan}

In the cases of social security reserve fund investment, the lesson of pension fund investment in Japan is particularly profound. Public pension reserve fund in Japan is known as annuity deposit, which belongs to the social security reserve fund. From 1961 to March 31, 2001, the annuity deposit in Japan (the reserve fund accumulated by the surplus funds after the annual pension expenses) accumulated to about 142 trillion yen, which is one of the biggest reserve assets in the world. The large-scale pension assets have been used by the government for the policy finance system of Fiscal Investment and Loan Program (hereinafter referred to as FILP) until March 2001. The application of funds can be roughly divided into four types: (1) loan money to the public treasury and community of government and other institutions (2) provide financing for the special accountant of the country (3) part of the funds can return to the postal savings account and direct invest in the financial market; (4) buy local government bonds. The four kinds of fund that make up the "FILP" are approved by Parliament every year. In addition, the remaining funds can be used to buy government bonds and short-term loans. However, in the research on this plan and annuity deposit in 2002 and 2003, some Japanese scholars pointed out that majority of pension reserve assets of several decades have become the bad debts. Most of the financial investment funds from the annuity deposit together with the postal savings and other funds are directly loaned to various financial institutions by the Ministry of funds application, and some funds are used for the purchase of government bonds. The composition of funds in Ministry of funds application during 1996-2000: $20 \%$ and 25\% are used for the purchase of government bonds while $75 \%$ to $80 \%$ are directly lent to various financial institutions. These investment projects had a large number of losses. Up to 2000 , the financial losses brought by investment behavior of social security fund and the estimated debt expenditure are estimated to reach 78.3 trillion yen. ${ }^{8}$

The reason is that during 1961-2001 Japan has not established a sound risk control and risk hedging mechanism in pension fund investment plan, so investment projects are affected by the financial institutions' own operations and the huge fluctuations in economic and social development and led to losses. Besides, the only goal of investing in social security funds that ensure the interests of

\footnotetext{
8 Deng Bingwen, Fang Lianquan, Wang Xin The Painful Lessons of "East Asia" Investment of Japan 's Social Security Fund, International Economic Review, 2005 (3): 26-32.
} 
beneficiaries have shifted, and part of them are used for the "social investment" to achieve staged economic and social development goals, resulting in an astonishing investment loss.

\section{VIEWING THE NECESSITY OF RISK CONTROL FROM THE NEW RISKS AROUSED BY CHINA'S "EXPANSION OF INVESTMENT" OF SOCIAL SECURITY FUND IN CHINA}

"Expansion of investment" of social security fund in China mainly exacerbates risks in the following aspects:

\section{A. Social Security Fund Investment Risk Triggered by the Local Government Debt Solvency}

Some of our local governments have lower debt solvency that leads to the potential new investment risk of social security funds. Since 2015, China allows social security funds to invest in local government bonds, and raise the proportion limit of investment in corporate bonds and local government debt from $10 \%$ to $20 \%$. However, according to the China National Balance Sheet released by Academy of Social Sciences in 2013, at the end of 2012, the scale of local government debt reached 19.94 trillion. Under the pressure of reimbursement and replacement of huge debt, the debt superposition effect caused by the issuance of new bonds increased the risk of investment in local debt and how the social security fund investment can avoid the risk has become the focus.

\section{B. The Lack of Exit Mechanism of Social Security Fund's Equity Investment and the Limitation of Unilateral Operation Make the Risk More Visible}

The scope of Social insurance fund direct equity investment is expanded to the central enterprises and their subsidiaries and local industry leading enterprises with core competitiveness including high-quality private enterprises from the past reform or pilot project of central management enterprises. On the one hand, the social security fund lack investment transfer mechanism and exit mechanism in the first-level securities market, so once the investment objective suffers risks, the investment may be completely annihilated. On the other hand, the National Social Security Fund Council is self-operated or entrusted by the third party to operate in the second-level securities market. Due to the only unilateral investment, and the lack of hedging tools, it is easy to incur losses facing the rose and fall of stock market. As mentioned earlier, the Social Security Fund's self-directed portfolio losses in 2010-2013 amounted to 9,953 million yen, which was staggering. The lack of risk hedges in the social security fund portfolio was an important reason.

\section{Raise in the Upper Limit of Trust Loans Investment Increases the Risk of Investment in Social Security Fund Projects}

Improvement of the upper limit of social security fund investment in the trust loan investment, in particular, increasing the engagement in affordable housing and urban infrastructure and other projects raise the risk management pressure of social security fund to the risk transfer of preliminary selection, interim monitoring and later default of trust products. For trust products, it is imperative to consider how to select and monitor the trust products in med-term and how to transfer risk when the default risk of trust occurs to minimize the investment losses of the social security fund due to the asymmetry of information.

V. IT IS THE NECESSARY WAY FOR CONTROLLING THE INVESTMENT RISK OF SOCIAL SECURITY FUND TO CONTINUE THE EXPANSION OF INVESTMENT AND ESTABLISH A COMPREHENSIVE HEDGE MECHANISM

According to the meeting requirements on April 1, 2015 , investment risk should be controlled when the social security fund assets are allocated to more fields with relatively high income to hold the "red line" of safety. The introduction of a comprehensive hedge mechanism after the "expansion of investment" of the social security fund is the necessary way to control investment risk. Wang Zhongmin, vice chairman of the Social Security Fund, pointed out that social security fund investment in China needs more liquidity, and "derivation and hedge" should be two important concept of social security fund investment, so we must establish a hedge mechanism. At present, social security fund investment in China is mainly unilateral operation while the real investment should have a reverse hedge to protect it. ${ }^{9}$ If there is no hedge mechanism, the risk for unilateral operation in the ups and downs of the market is very high. For example, Social Security Fund selfindexed portfolio loss in China in 2013 is 1.47 billion yuan $^{10}$, for which the continuous fall of overall stock market is the surface causes while the deeper reason is the lack of hedge tools like stock index futures in portfolio to resist and resolve the risk of integral volatility of the stock market. "Hedging is a major performance of the stabilizer" ${ }^{11}$, so adding more investment tools to hedge and establishing a perfect hedge mechanism will make investment more stable. Therefore, in the context of the current modest "expansion of investment", we should further "expand" the investment, extend and derive the chain of investment products of social security fund, add more diversified investment vehicles and risk-taking entities to build a new social security fund investment structure and product portfolio with balance risk and income, including the extension of the financial product chain, introduction and development of new hedge products and guarantee and re-guarantee subjects, which can truly break the shackles of unilateral operation and one-way operation and full play the role of hedge mechanism to protect social security fund investment.

\footnotetext{
9 Chen Xu. Wang Zhongmin, vice chairman of the Social Security Fund: hedging is a major performance of the stabilizer Economic Observer, http://www.eeo.com.cn/2011/1103/214883.shtml, 2011-11-3/2017-07-02.

10 Report of the Social Security Fund Management and Budget Performance in 2013 and Other Financial Revenue and Expenditure Audit Results issued by Audit Office in 2014.

11 Chen $\mathrm{Xu}$. Wang Zhongmin, vice chairman of the Social Security Fund: hedging is a major performance of the stabilizer Economic Observer, http://www.eeo.com.cn/2011/1103/214883. shtml, 2011-11-3/2017-07-02.
} 


\section{COUNTERMEASURES AND SUGGESTIONS FOR CONTINUOUS EXPANSION AND ESTABLISHMENT OF A COMPREHENSIVE RISK HEDGING MECHANISM}

Combined with the national conditions of China, it is suggested to set about in the following aspects to continue to "expand" the social security fund and establish a comprehensive risk hedging mechanism:

\section{A. Open the Investment in Stock Index Futures Products of Social Security Fund to Hedge the Systemic Risk of Securities Market}

Social security fund investment in the securities market still only adopts the one-way operation, with the lack of tools to fight against the fall in stock market. It can gain benefits when the stock market rise, but can only bear the loss when the stock market decline. China has set up stock index futures financial products in 2010 , as the extremely important hedging and reverse hedging tools for the market, which can earn benefits by selling more when the overall stock market rise and make profit by short selling when the stock market falls. Application of two-way operation can play the role of stabilization. The current key is to let go and allow the social security fund to use the weapon of stock index futures to defense the overall market volatility and hedge the systemic risk of securities market.

\section{B. Open the Physical Gold and Gold Futures Investment to Resist the Risk of External Disk Fluctuations}

With the acceleration of integration process of global financial markets, linkage between securities market in China and the outer disk, especially the US disk becomes significant, so the sharp fluctuations in US stocks often affect the securities market in China. And theoretical research and financial practice in nearly half a century shows that the gold price and the US stock market price index show a reverse relationship, in which the gold price generally rise steadily when the US stock market decline. During the US subprime crisis, global gold prices rose more than $100 \%$. Therefore, the physical gold and gold futures products can be used as an important tool for social security fund of China to hedge the risk of external disk.

\section{Open Investment in Securities Margin Trading Products to Hedge the Impact of Single Stock Volatility}

The expansion of investment of social security fund equity increases the probability of investment risk caused by single stock volatility while the two-way operability of securities margin trading products for single stock provides an opportunity for social security fund to hedge the risk of single stock volatility.

\section{Allow the Introduction of Security Mechanisms and the Purchase of Security Services When Social Security Funds Invest in Local Debt}

For the precaution of risk in social security fund investing in local debt, one is the social security fund can establish a set of their own local debt risk rating mechanism when it refers the risk rating mechanism for local bond from financial institutions, thus making the risk identification, risk warning and risk monitoring. Second, when we allow the social security fund to invest in local bonds the local government should provide collateral, including local tax revenue or specific project income as security, such as stateowned capital operating income and land transfer income. Third, on the basis of the collateral provided by local government, we allow social security funds to re-guarantee when third-party institutions is introduced so as to comprehensively transfer and hedge the risk of social security fund investing in local debt.

\section{E. Introduce Re-guarantee Mechanism for Prevention and Control of Investment Risk in Trust Products}

With the expansion of the range of the trust project invested by social security fund after the expansion of investment, the corresponding risk control issues become more important. It is recommended that, first of all, the social security fund should be required to introduce other institutions of strong strength to re-guarantee on the basis that institutions with good credit such as the local government has provided guarantee when it make investment. Second, we need to construct a multi-level risk management system for project selection, supervision on project operation and recoupment of project default, and innovate different risk hedging and transformation tools for different risk factors to establish a comprehensive risk management mechanism for trust project investment.

\section{CONCLUSION}

"Expansion of investment" of social security fund brings the opportunity of appreciation on investments and provides a strong financial support for achieving the equalization of public service in the whole society, but it contains a new huge investment risk. Establishment of a comprehensive risk hedge mechanism is exactly the powerful tool of protection and stabilization of the social security fund investment. Therefore, on the basis of the expansion of investment, the "expansion" should be further carried out and introduction of diversified, multi-level investment derivatives and hedging tools is imperative.

\section{REFERENCES}

[1] Wu Zhong, Wang Yuxi. Risk management model of social security fund investment based on CDaR theory, Business Studies, 2009 (387): 106.

[2] Deng Bingwen, Fang Lianquan, Wang Xin The Painful Lessons of "East Asia" Investment of Japan 's Social Security Fund, International Economic Review, 2005 (3): 26-3.

[3] Li Xiangjun. Research on Investment Management of Social Security Fund in China Beijing: Chinese academy of fiscal sciences, 2010

[4] Report of the Social Security Fund Management and Budget Performance in 2013 and Other Financial Revenue and Expenditure Audit Results issued by Audit Office in 2014.

[5] Chen Yan. Investment expansion of 1.5 trillion national social security fund Portal of central government http://www.gov.cn/xinwen/2015-04/02/content_2841808. htm, 201504-02/2017-07-02-04-02. 
[6] National Council for social security fund http://www.ssf.gov.cn/jj/qgsbjj/201501/t20150121_6316. html, 201501-21.

[7] Chen Xu. Wang Zhongmin, vice chairman of the Social Security Fund: hedging is a major performance of the stabilizer Economic Observer, http://www.eeo.com.cn/2011/1103/214883. shtml, 201111-3/2017-07-02. 